\title{
喉頭喘鳴をきたす小児疾患の検討
}

\author{
小林 英人・渡辺 行雄・吉田 行夫 \\ 麻生伸 ·大橋 直樹・水越 鉄理
}

\section{Laryngeal Stridor in Infants}

\author{
Hideto Kobayashi, Yukio Watanabe, Yukio Yoshida, \\ Shin Aso, Naoki Ohashi and Kanemasa Mizukoshi \\ (Toyama Medical and Pharmaceutical University)
}

In thirteen infants with laryngeal stridor admitted in our hospital, foreign bodies in the bronchi were observed in 7 cases. Three cases of laryngomalacia, one vocal cord nodule, one difficulty in decannulation after tracheostomy, one hypopharyngeal cyst were also revealed. We reported a case of hypopharyngeal cyst causing severe deviation of his larynx. The importance of recognizing the etiology of laryngeal stridor in infants by using direct laryngoscopy under general anesthesia is emphasized.

Key words: laryngeal stridor, hypopharyngeal cyst, laryngoscopy, general anesthesia

はじめに

喉頭喘鳴をきたす小児疾患としては喉頭軟弱 症 laryngomalacia が良く知られており, 喉頭 軟弱症の場合には積極的な処置は行わずに経過 を観察しながら成長を待つことも多い。しかし， 先天性奇形や炎症, 異物などでも喉頭喘鳴をき たすことがあり，早期確定診断が望まれる。そ こで今回私共は, 開設以来当科で取り扱った小 児の㬋頭喘鳴症例について検討を加え, 鑑別診 断上興味ある症例を経験したのでその臨床経過 の概要について報告する。

\section{対象}

1979年10月の富山医科薬科大学附属病院開設 以来1989年 5 月までの 9 年 8 力月の間に当科で 入院精査した 5 歳未満の喉頭喘鳴を主訴とした 13例である。
結果

表 1 に示すように気管支異物 7 例, 喉頭軟弱 症 3 例, 声帯結節, カニューレ抜去困難症, 下 咽頭䨞胞各 1 例である. 気管支異物やカニュー レ抜去困難症以外の 5 例では生下時からの喉頭 喘鳴を訴えており, 他科や他院にて先天性喉頭 喘鳴の診断を受けていた。

このらち高度の喉頭偏位をきたした下咽頭囊 胞について紹介する。

\section{症例}

症例 : 11力月 男児

初診日：1982年 4 月 5 日

主訴：喉頭喘鳴, 陥没呼吸

現病歴: 生下時より喘鳴, 陥没呼吸が強く, 近医より紹介され当科を受診し精査目的で入院 となった。 
家族歴：特記すべき事項なし。

既往歴: 出生時体重 $3400 \mathrm{gr}, 10$ 力月満期産. 初診時所見：体重 $6400 \mathrm{gr}$, 身長 $64 \mathrm{~cm}$. 発 育やや不良。泣鳴時にはチアノーゼを呈したが， 曣下障害はみられなかった。神経学的, 血液生 化学的検查に異常はみられない。

$\mathrm{X}$ 線検查所見：喉頭断層写真（図 1) では喉 頭が高度に右方偏位して扮り, 実質性の腫瘍陰

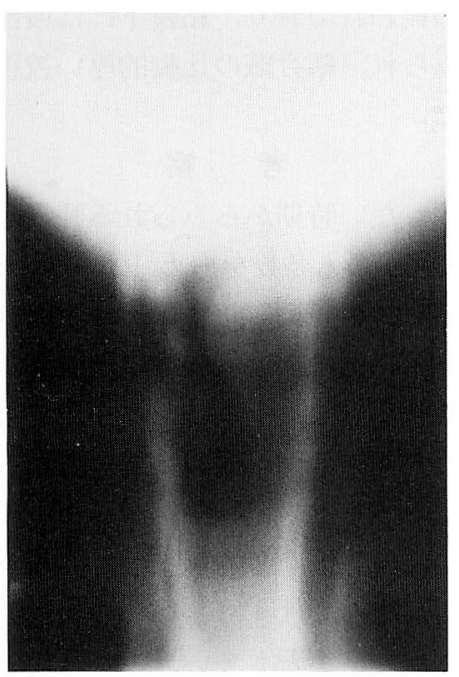

図 1 喉頭断層写真
影がみられた。CT（図2）では気管の左側に 充実性の腫溜状院影を認めた。

入院時経過: X線検查所見加先天性喉頭腫 瘍に上る喉頭狭搾を疑い，6月７日全麻下喉頭 鏡検查目的でマスク導入し挿管を試みた。しか し㘠 3 に示すように本来の左仮声帯付近上り腫 瘤が声帯を高度に圧迫し披裂軟骨部近くの極め て狭い間隙から辛うじて呼吸をしている状態で あった，挿管が不可能であったため，まず気管 切開し気道を確保した.7月28日,体重が 8000 gr に達した時点で, 全麻下に左側頸部から下 咽頭を切開し，梨状陥凹にあった腫瘤を摘出し たところ, 約 $3 \mathrm{ml}$ のゲル状内容物を含む囊胞

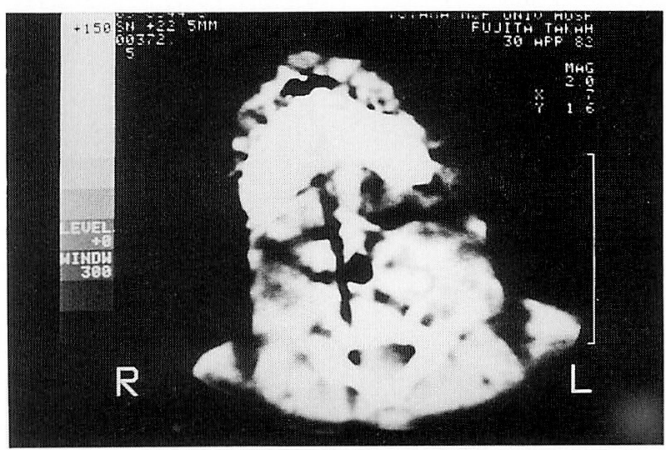

図 $2 \mathrm{CT}$ 像

表 1 小児の喉頭喘鳴症例

富山医薬大耳鼻咽喉科１979.10-1989.5

\begin{tabular}{|c|c|c|c|}
\hline 症 例 & 年 踰 & 性 別 & 㡎 \\
\hline & 2 歳 3 力月 & 우 & 気管支異物（プラスチック玩具） \\
\hline & 2 歳 1 力月 & $\hat{\jmath}$ & 気管支異物（ピーナッツ） \\
\hline & 1 歳 2 力月 & $\delta$ & 気管支異物（ピーナッッ） \\
\hline & 2 歳 0 力月 & $\hat{\delta}$ & 気管支異物（ピーナッツ） \\
\hline & 1 歳 7 力月 & $\delta$ & 気管支異物（クルミ） \\
\hline & 1 歳 9 力月 & q & 気管支異物（ピーナッツ） \\
\hline & 1 歳 1 力月 & 우 & 気管支異物（ピーナッツ） \\
\hline & 4 力月 & $\hat{\delta}$ & 喉頭軟弱症 \\
\hline & 1 力月 & q & 喉頭軟弱症 \\
\hline & 1 力月 & o & 喉頭軟弱症 \\
\hline & 2 歳 4 力月 & ㅇ & 声带結 節 \\
\hline & 3 歳 3 力月 & $\delta$ & カニューレ抜去困難症 \\
\hline & 11 力月 & $\hat{o}$ & 下咽頭需胞 ～～～～～～ \\
\hline
\end{tabular}


がみられた。この囊胞は下咽頭と喉頭の間に位 置し, 甲状軟骨左板の後部で喉頭全体を右方へ 強く圧迫偏位させていた（図 4)。したがって 本症例は下咽頭粘膜下組織より発生し, 高度の 喉頭偏位をきたした先天性下咽頭囊胞と診断し た。摘出後は下咽頭から声門上腔に充分なス ペースのあることが確かめられ，内視鏡的にも 咽頭が正常の位置に戻され声門も確認された。 術後は気管カニューレを長期間挿入したため, 一時期カニューレ拔去困難症になったが体重増

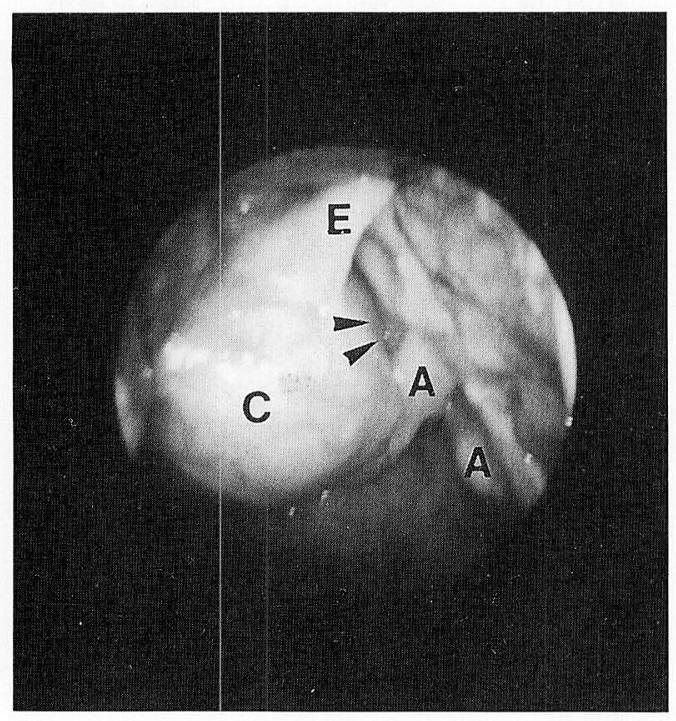

図 3 喉頭鏡所見

矢印が声門間隙を示す。

$\mathrm{C}$ : 囊胞 $\mathrm{E}$ : 喉頭蓋 $\mathrm{A}$ ：披裂軟骨部
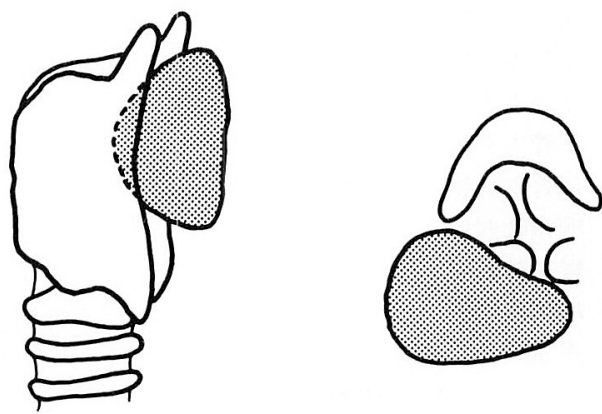

図 4 囊胞存在部位のシェーマ
加に伴い軽減した。その後, 声带の動きを観察 しながら，声門が開大し充分呼吸できることを 確認し, 体重が $9500 \mathrm{gr}$ に至った時点で気管カ ニューレを抜去して退院となった。退院後の経 過は良好で順調に発育し，7歳10力月時に行っ たファイバースコピーでも正常な喉頭所見を呈 していた，発声についても障害はみられなかっ た.

病理的組織所見（図 5 ）: 囊胞内腔は繊毛円 柱上皮に被われて拈り, 粘膜下には慢性炎症の 所見がみられ，結合織の比較的厚い被膜に囲ま れていた。

\section{考察}

生後間もない時期からみられる呼吸障害では 喉頭軟弱症が最も多数を占め, 1987年の Hawkins ら1)の報告では呼吸障害を訴光た 4 歳以下の症 例264例中113例に喉頭軟弱症の所見を認めてい る. 私共の症例でも生下時から喉頭喘鳴をきた していた 5 例中 3 例が喉頭軟弱症であった。喉 頭軟弱症の多くは小児科や，産科領域で扱われ， 発育につれ自然治癒する例も多くみられるため 積極的な治療は受けずに，局所の状態すら詳し く観察されないことも多い。これに対して 1 ， 2 歳時に多くみられる啹頭喘鳴は気道異物であ ることが多く2）当科の症例でも 8 例中 7 例が気 管支異物であった。したがって，生後間もない 時期からみられる喉頭喘鳴では喉頭軟弱症を 1 , 2 歳頃に突然現われる時には気道系の異物をま

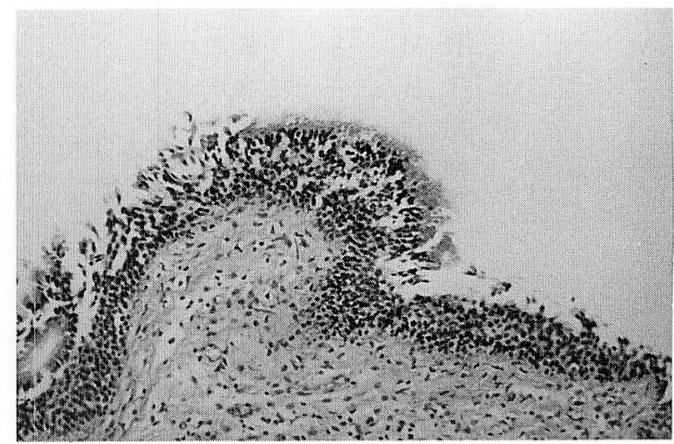

図 5 病理組織所見 
ず念頭に置いて診断や治療にあたる必要がある. 次に，今回経験した下咽頭囊胞について検討を 加学る。

喉頭および下咽頭周辺にみられる良性腫瘍の

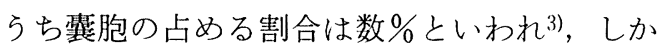
もその発生部位は喉頭蓋, とくにその舌面にみ られるものが王倒的に多いとされている4).こ の点, 自験例の如く下咽頭粘膜下ょり発生した 症例は極めて稀なものと思われる. 同様な症状 を呈した例として, 本邦では1975年に 1 歳 9 力 月の女児の先天性喉頭内裂腫症例が報告されて (る5).

先天性囊胞の成因について Gras ${ }^{4)}$ は胎生期 に迷入した肧芽からの発生, 咽頭溝からの発生, 甲状舌管からの発生に分類しているが, 咽喉頭 は複雑な過程を経て形成されるためその起源を 正確に鑑別することは困難とされる．本症例は， 組織学的には繊毛円柱上皮に被われており brachical cleft 由来の囊胞と推察した。

続いて, 正中頸霊胞や側頸霊胞との鑑別につ いて述べる. 両者とも組織学的所見からは特殊 な場合を除いて鑑別不可能といわれている6 しかし, 正中頸囊胞つまり甲状舌管由来の囊胞 は，正中位で舌盲孔付近にある場合を除外すれ ば前頸部の外から触診できるのが普通である. とくに下咽頭や喉頭などに存在し, 口腔内から の久観察される囊胞が正中頸襄胞であったとの 報告は私共の渉猟する限りみられなかった。さ らに側頸霊胞については左右に存在するもので あり, 喉頭正中付近に基底の中心を有する囊胞 については側頸霬胞である可能性は少ないとい

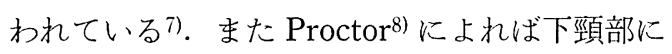
側頸垶胞が見られる時には, 皮䖉に㾇孔をつく ることも多いといら ${ }^{99}$.

治療としては外科的な全摘出術になるが，小 児であるために気道系の検索が難しく診断に苦 慮したり，喉頭軟弱症として見過ごされ発見が 遅れることも少なくないとみられる. Larsen ら 10) は喉頭喘鳴を訴える新生児に対してルー チンに無麻酔の直接喉頭鏡検査を行っているが，
近年では気管食道科学や麻酔学の進歩に伴い, 小児の気道系の検査や手術も比較的安全に行え るよらになってきた。したがって，小児期にお ける反復する喘鳴, 呼吸困難などを訴え, 無麻 䣷や局麻下の検査所見だけでは確定診断のつか ない症例に対しては積極的に全麻下に喉頭，下 咽頭，気管などを観察することが必要と思われ る.

\section{まとめ}

開設以来当科で入院精査した 5 歳未満の喉頭 喘鳴を主訴とした症例は13例あり，その内訳は 気管支異物 7 例, 喉頭軟弱症 3 例, 声帯結節, カニューレ抜去困難症, 下咽頭囊胞各 1 例であ った。このらち高度の喉頭偏位をきたした下咽 頭慗胞症例を紹介し, 全麻下喉頭鏡検査の重要 性を強調したい。

本論文の症例については第35回日本気管食道科学 会（1983年11月19日，大阪）にて口述報告をした。

\section{文 献}

1) Hawkins DB and Clark RW : Flexible laryngoscopy in neonates, infants, and young children. Ann Otol Rhinol Laryngol 96 : 81 85, 1987.

2）薗田史子, 山本裕幸, 山中泰輝, 他: 小児喉頭 異物症の 1 例. 耳展 $32: 289 \sim 293,1989$.

3) New GB and Erich JB : Benign tumors of the larynx. Arch Otolaryngol $28: 841 \sim 910,1938$.

4) Glas E : Ueber Larynxcysten. Arch für Laryng Rhinol $19: 285 \sim 305,1907$.

5) 大浦正則, 足川力雄, 高野元英, 他 : 乳児の先 天性喉頭袋腫症の 1 治験例. 耳展 $18: 377 \sim 381$, 1975.

6）綿貫幸三，高坂知節，草刈 潤，他：正中頸䓂 胞12例. 耳喉 $53: 167 \sim 172,1981$.

7) 綿貫幸三, 高坂知節, 草刈 潤: 喉頭㐮胞 14 例, 日耳鼻 $85: 766 \sim 776,1982$.

8) Proctor $B:$ Lateral vestigial cysts and fistulas of the neck. Laryngoscope $65: 355 \sim 401,1955$.

9）小林英人, 加藤 功, 青柳 優, 他: 先天性頸 部裂胞の検討. 耳番 $27: 500 \sim 504,1981$. 
10) Larsen M, Peitersen B and Peitersen E : Strider in new borns. Acta Otolaryngol Suppl $412: 28 \sim 29,1984$.
(別刷請求先 : 小林英人 宁930-01 富山市杉谷 2630

富山医科薬科大学医学部耳鼻咽喉科学教室) 